\title{
Developmental biology, polymorphism and ecological aspects of Stiretrus decemguttatus (Hemiptera, Pentatomidae), an important predator of cassidine beetles
}

\author{
Lucia Maria Paleari ${ }^{1}$
}

\begin{abstract}
'Instituto de Biociências Universidade Estadual Paulista “Julio de Mesquita Filho, Rubião Jr. s/n, Caixa Postal 510, 18618-970 Botucatu-SP, Brasil. lpaleari@ibb.unesp.br
\end{abstract}

\begin{abstract}
Developmental biology, polymorphism and ecological aspects of Stiretrus decemguttatus (Hemiptera, Pentatomidae), an important predator of cassidine beetles. Stiretrus decemguttatus is an important predator of two species of cassidine beetles, Botanochara sedecimpustulata (Fabricius, 1781) and Zatrephina lineata (Fabricius, 1787) (Coleoptera, Cassidinae), on the Marajó Island, Brazil. It attacks individuals in all development stages, but preys preferentially on late-instar larvae. Its life cycle in the laboratory was $43.70 \pm 1.09$ days, with an egg incubation period of six days and duration from nymph and adult stages of $16.31 \pm$ 0.11 and $22.10 \pm 1.67$ days, respectively. The duration of one generation $(T)$ was 12.65 days and the intrinsic population growth rate ( $r$ ) 0.25 . These data reveal the adjustment of the life cycle of $S$. decemgutattus with those of the two preys, but suggest greater impact on Z. lineata. However, no preference over cassidine species was shown in the laboratory. Up to 17 different color patterns can be found in adults of $S$. decemguttatus, based on combinations of three basic sets of color markings. Some of them resemble the markings of chrysomelids associated with Ipomoea asarifolia (Convolvulaceae) and are possibly a mimetic ring. Three color patterns were identified in nymphs, none of which was associated with any specific adult color pattern.
\end{abstract}

KEYWORDS. Asopinae; color pattern; Ipomoeae asarifolia; life table; predation.

Stiretrus decemguttatus (Hemiptera, Pentatomidae, Asopinae) is a South American polymorphic species (Thomas 1992) and a predator of Chrysomelidae. In 1953, Bondar recorded it attacking larvae and adults of Zatrephina lineata (Fabricius, 1787) on São Luis Island, Maranhão State, Brazil, while Van Doesburg (1970) detected its attacks on larvae and pupae of Paraselenus flava (Linnaeu, 1758) in Suriname.

Natural history data about this predator are unknown, probably due to the paucity of studies about its Cassidinae prey (Buzzi 1988; Buzzi, 1994; Moura \& Grazia 2011). In 1990 , the author of this paper observed $S$. decemgutattus, in the city of Salvaterra, attacking Botanochara sedecimpustulata (Fabricius, 1781) and Zatrephina lineata, chrysomelid leaf-eaters of Ipomoea asarifolia (Ders.) Roem. \& Schult. (Convolvulaceae). Consequently, it is expected that the predator can play a fundamental role in the coexistence pattern of these Cassidinae beetles, according to the specific degree of vulnerability of each of these prey (Freeland 1983; Lawton 1986).

Investigations into the life cycle and aspects of the predation ability of $S$. decemguttatus on eggs, larvae, and pupae of $B$. sedecimpustulata and Z. lineata could evaluate the importance of this predator on populations of these prey and the consequences for community structure of herbivorous insects feeding on Ipomoea asarifolia. Because it is a polychromatic species (Thomas 1992; Van Doesburg 1970), whose color morphs exhibit very similar patterns to those of Stiretrus decastigmus morphs (Poncio et al. 2010), there is a need to study ecological genetics of $S$. decemguttatus, since differences in fecundity, viability, mating forms, seasonal frequencies, and mimetic relationships of individuals with different patterns, which have been detected for several species (Ford 1975; Bourdouxhe \& Jolivet 1981; Vasconcellos-Neto 1988; Paleari 1994), may determine particular adjustments of the predator to each Cassidinae prey.

In the present study, a field survey was conducted to characterize the different color patterns of adults and nymphs Stiretrus decemgutattus found on the Marajó Island and laboratory data on the prey species and stage preference and on its life cycle are also given.

\section{MATERIAL AND METHODS}

The stages of research set out below and further described in specific items were developed in the city of Salvaterra $\left(00^{\circ} 45^{\prime} 12^{\prime}\right.$ ' S, $\left.48^{\circ} 31^{\prime} 00^{\prime \prime} \mathrm{W}\right)$, at the Marajo Island, Pará State. Climatic data were recorded at the Meteorological Station of the National Institute of Meteorology, INMET (004 'S, $48^{\circ} 31^{\prime} \mathrm{W}$ ), in the city of Soure (Fig. 1).

General observations on the natural history of $S$. decemgutattus, in vacant lots in the cities of Salvaterra and Soure, took place in 1990. In 1991, a field survey was carried out in the city of Salvaterra to observe polymorphism and ecological aspects of this predator. In parallel, to better understand and analyze behavioral aspects of $S$. decemgutattus, a broad study was conducted on the biology and popu- 
lation dynamics of their Cassidinae prey, Botanochara sedecimpustulata and Zatrephina lineata, which will be the subject of future papers.

Color polymorphism. Color patterns of $S$. decemgutattus observed for thirty-four months in field and laboratory were described and some were also photographed and drawn. A reference collection was organized and deposited at the $\mathrm{Mu}$ seum of Zoology "Professor Adão José Cardoso", State University of Campinas.

In the field, from May 1991 to May 1993, data on $S$. decemgutattus were obtained during surveys of Cassidinae prey, according to the methodology of Paleari (1997), which included examining $I$. asarifolia once a month in: a) an area of $100 \mathrm{~m}^{2}$ of a farm located in the vicinity of Salvaterra, b) within thirty patches which were growing in sidewalks and streets of Salvaterra. Nymphs and adults of S. decemgutattus were recorded and their color patterns were also described.

Laboratory experiments. In December 1993, four females of the predator were used to start a laboratory population, which was kept in captivity until March 1994, in a balcony surrounding the building. This balcony was protected with mosquito screen and it was under ambient temperature and relative humidity.

Food preference tests. Ten males and 10 females of $S$. decemguttatus were starved during $12 \mathrm{~h}$ and individualized on Petri dishes (10 cm diameter) covered with moist filter paper. Each dish contained a portion of I. asarifolia leaf (3.5 $\mathrm{cm}$ diameter) with a clutch of eggs, a pupa, and a larva from each instar of B. sedecimpustulata, the most abundant species at the site. This set was renewed seven times for each one of the 20 bugs tested. Observations and data records of each series were carried out once a day, for up to $4 \mathrm{~h}$, in the afternoon, and referred to the behavioral aspects and the phase of the first Cassidinae caught by the 140 adult $S$. decemguttatus. This period was based on previous observations of $S$. decemgutattus towards their prey, which were often attacked and consumed after two to three hours.

Adults of B. sedecimpustulata were excluded from the tests because of the rarity of attacks on individuals in this stage. The preference of $S$. decemgutattus for B. sedecimpustulata and the $Z$. lineata prey was tested using the same Petri dishes described above, each with one fifth-instar larvae of each cassidine species. Preparations were also renewed in each of the seven repetitions, after observation and record of the first predated species in the 4-hour period.

Developmental biology. Egg clutches with 60 eggs from four females (Patterns 2, 3 and 5-Table I) of S. decemguttatus collected in vacant lots in Salvaterra were placed in labeled transparent jars ( $4 \mathrm{~cm}$ high by $2.5 \mathrm{~cm}$ in diameter).

After hatching, the nymphs were kept for one day with the chorion and, after the first molt, placed in individual plastic boxes ( $10 \mathrm{~cm}$ length by $7 \mathrm{~cm}$ width and $4 \mathrm{~cm}$ height). To provide ventilation, an area of $12.5 \mathrm{~cm}^{2}$ was cut out of the lids and replaced with organza. The bottom of each box was lined with slightly moistened absorbent paper upon which was placed a leaf of Ipomoea asarifolia, the food of the Cassidinae prey.

Molt of each individual at the end of each day was recorded, the box was cleaned, and a fresh I. asarifolia leaf and 4 fifth instar larvae of $B$. sedecimpustulata offered to $S$. decemgutattus were placed in it. All prey offered to the asopine nymphs and adults in captivity were collected in the field.

Upon emerging, the adults of $S$. decemgutattus were identified and characterized per sex and color pattern. Then, 24 pairs were organized and each one was kept in a box similar

Table I. Descriptions of color patterns of variegated and non-variegated adults of Stiretrus decemguttatus found in Salvaterra and Soure, Pará State, Brazil and offspring phenotypes in the developmental biology study (see table IV).

\begin{tabular}{|c|c|c|c|c|c|c|c|}
\hline \multirow{2}{*}{ Pattern } & \multicolumn{3}{|c|}{ Dorsal aspect } & \multirow{2}{*}{$\begin{array}{l}\text { Pattern } \\
\text { number }\end{array}$} & \multicolumn{3}{|c|}{ Offspring phenotype } \\
\hline & Spot design & Spot color & Background (scutelum-corium)/Head-leg & & Male & Female & Nymphs \\
\hline \multirow{9}{*}{ Variegated } & \multirow{5}{*}{ Elongated } & \multirow[t]{3}{*}{ Black or Median-brown } & Whitish & 1 & 19 & 0 & $3 \mathrm{C} 1-2$ \\
\hline & & & Whitish with median-brown stains & 2 & 4 & 3 & $3 \mathrm{C} 1-2$ \\
\hline & & & Red & 3 & 0 & 2 & $3 \mathrm{C} 1$ \\
\hline & & Dark red & Whitish & 4 & 1 & 0 & $3 \mathrm{C} 2$ \\
\hline & & Median-brown & Whitishwith plenty of median-brown & 5 & 0 & 0 & 0 \\
\hline & \multirow{4}{*}{ Circular } & \multirow{3}{*}{$\begin{array}{l}\text { Creme - sometimes with } \\
\text { red streak }\end{array}$} & Wine & 6 & 1 & 0 & $3 \mathrm{C} 3$ \\
\hline & & & Dark red & 7 & 2 & 0 & $3 \mathrm{C} 3$ \\
\hline & & & Black & 8 & 0 & 0 & 0 \\
\hline & & $\overline{\text { Red }}$ & Black & 9 & 0 & 0 & 0 \\
\hline \multirow{8}{*}{ Not variegated } & \multirow{2}{*}{ Not metallic } & & head and legs ochre & 10 & 0 & 6 & $3 \mathrm{C} 1$ \\
\hline & & & Median-brown head and legs black & 11 & 0 & 4 & 3 C $1-2$ \\
\hline & \multirow{6}{*}{ Metallic } & & \multirow{2}{*}{$\begin{array}{l}\text { head and legs ochre } \\
\text { head and legs black }\end{array}$} & 12 & 0 & 5 & $3 \mathrm{C} 1$ \\
\hline & & & & 13 & 0 & 2 & $3 \mathrm{C} 1-2$ \\
\hline & & & \multirow{2}{*}{$\begin{array}{l}\text { head and legs blue } \\
\text { head and legs ochre }\end{array}$} & 14 & 0 & 1 & $3 \mathrm{C} 2$ \\
\hline & & & & 15 & 1 & 0 & $3 \mathrm{C} 2$ \\
\hline & & & \multirow{2}{*}{$\begin{array}{l}\text { head and legs violet } \\
\text { head and legs ochre }\end{array}$} & 16 & 0 & 2 & $3 \mathrm{C} 1$ \\
\hline & & & & 17 & 0 & 0 & 0 \\
\hline
\end{tabular}


to the one used for the nymphs, with the same feeding routine, $9^{\text {th }}$ and $12^{\text {th }}$ day pupae. Subsequently, with the scarcity of immature stages, each breeding box received a pair of $B$. sedecimpustulata.

Daily records kept for each of these pairs consisted of the behavioral aspects, number of clutches, and their respective number of eggs and hatchings, sex and color pattern of the descendants, as well as the number of larvae consumed during the first four days after mating.

\section{RESULTS}

Climatic conditions and ecological aspects of the predator and their cassidine prey. All the adults and nymphs of Stiretrus decemguttatus observed in the field were found on patches of Ipomoea asarifolia, with cassidine populations of Botanochara sedecimpustulata and Zatrephina lineata, especially in the rainy season (Fig. 1). The asopine bugs were found feeding mainly on late instar cassidine larvae (Fig. 2E and $3 \mathrm{C}$ ). In only one situation a female adult of $B$.
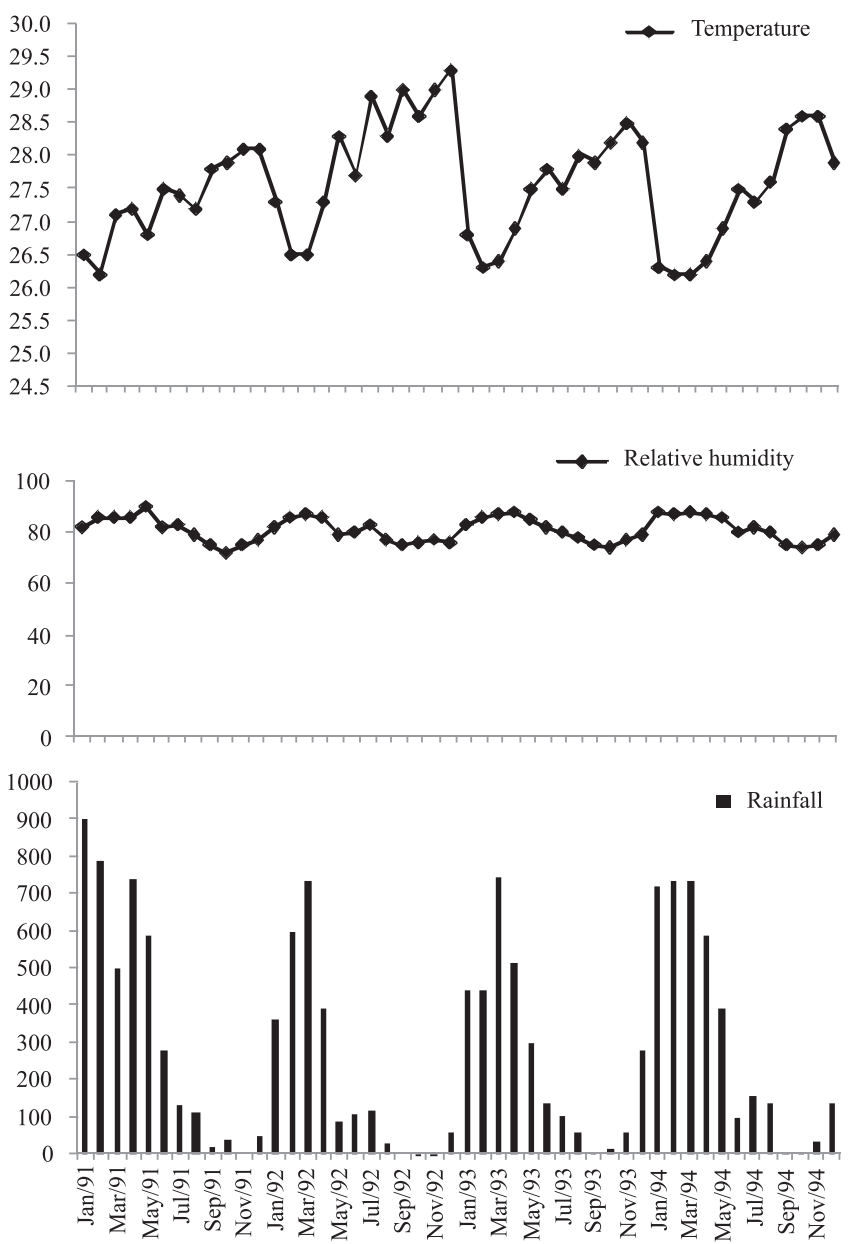

Fig. 1. Mean monthly values of temperature $\left({ }^{\circ} \mathrm{C}\right)$ relative humidity $(\%)$ and rainfall (mm) from January 1993 to December 1994 in Soure $\left(00^{\circ} 44^{\prime} \mathrm{S}\right.$, $48^{\circ} 31^{\prime} \mathrm{W}$ ), Marajó Island, Pará State, Brazil (Source: National Institute of Meteorology - INMET). sedecimpustulata was attacked by $S$. decemgutattus (Fig. 2D). The only egg clutches (Fig. 3A) detected in the field were camouflaged in dry calyxes of Sida sp. (Malvaceae) growing in a patch of $I$. asarifolia. These two cassidines were the most abundant prey of $S$. decemguttatus in Salvaterra and Soure. Botanochara impressa and Chelymorpha aff. alternans, other vulnerable species, were observed sporadically in the field, usually as solitary adults.

Around mid-December, B. sedecimpustulata restarted their feeding and breeding activities, after diapause that kept them inactive for up to nine months. Around March, the population of this cassidine prey had greatly increased, with an abundance of larvae damaging the host plant Ipomoea asarifolia. Population size of $Z$. lineata, a species that does not undergo diapause, had also increased, but its number remained below that of $B$. sedecimpustulata. The increase in the number of larvae was followed by the number of nymphs and adults of $S$. decemgutattus.

Color patterns of $\boldsymbol{S}$. decemgutattus recorded. Color patterns of hundreds of adults observed could be classified into 17 morphs, showing uniform (without spots) or variegated patterns (Fig. 2). The former comprise metallic (Fig. 2A 15 and 2F pair) and non-metallic (Fig. 2A 9 and 10) colors (Table I, patterns 10 to 17), while variegated adults display variable patterns, i.e., circular (Figs. 2A 1, 2B 2 and 2E) or elongated (Figs. 2A 2 to 8 and 11 to $14 ; 2 \mathrm{~B} 3$ to $6 ; 2 \mathrm{D}$ ) maculae on the dorsal area (Table I, patterns 6 to 9 and 1 to 5 , respectively). Depending on the degree of fusion of the elongated maculae, individuals will present eight to $10 \mathrm{macu}-$ lae, while individuals with circular designs invariably present 10 maculae. Patterns 2, 4 (Figs. 2A 2 to 8 and 11 to 14), 10 (Fig. 2A 9 and 10), and 11 were the most common in the field and laboratory (Table I, offspring phenotype). The rarest, 8 and 9 (Fig. 2E), observed only in 1991 and 1994, respectively, seem to be phenotypes more common in males.

In the period of drought (Fig. 1) and diapause of $B$. sedecimpustulata prey, we recorded the appearance of a large number of adults of an Eumolpinae (Chrysomelidae), rare at other times of the year, which was also feeding on the tender leaves of I. asarifolia, and whose color patterns resembled patterns 14 to 17 of $S$. decemguttatus (Fig. 2F).

Color patterns of nymphs (Figs. 3C and 3D) were divided in three phenotypes, with types C1-D1 and C2-D2 being the most common and involving warning colors. Type C1-D1 consists of a black head, thorax, wing pads, legs, and abdominal markings, with the rest of the abdomen red or reddish-orange. Type C2-D2 differs from C1-D1 only by the presence of two reddish markings on the thorax, and the head that may be all red. Nymphs of the third phenotype (Figs. 3C 3 and 3D 3) are rarer and completely orange. Nymphs with this pattern collected in the field, resulted in adults with the color pattern eight. Nymphs with different phenotypes in the fifth instar may originate adults with a similar pattern, while a pair with a given pattern may produce offspring with individuals of different color patterns, even from the same egg clutch. 


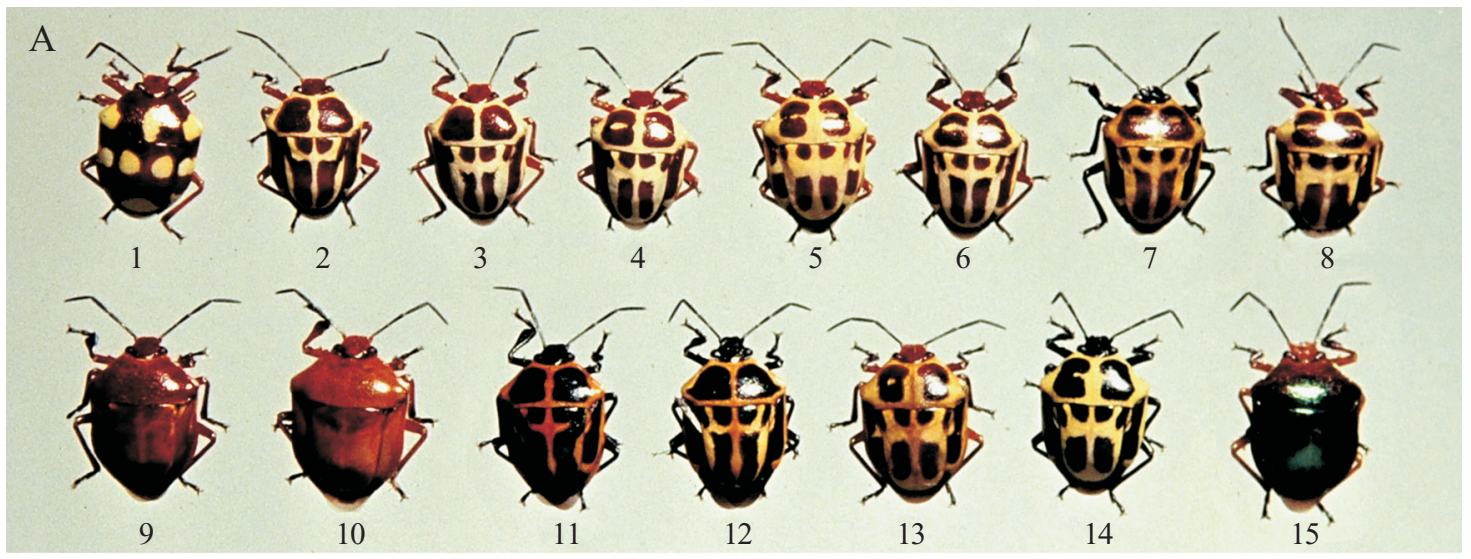

$\mathrm{B}$
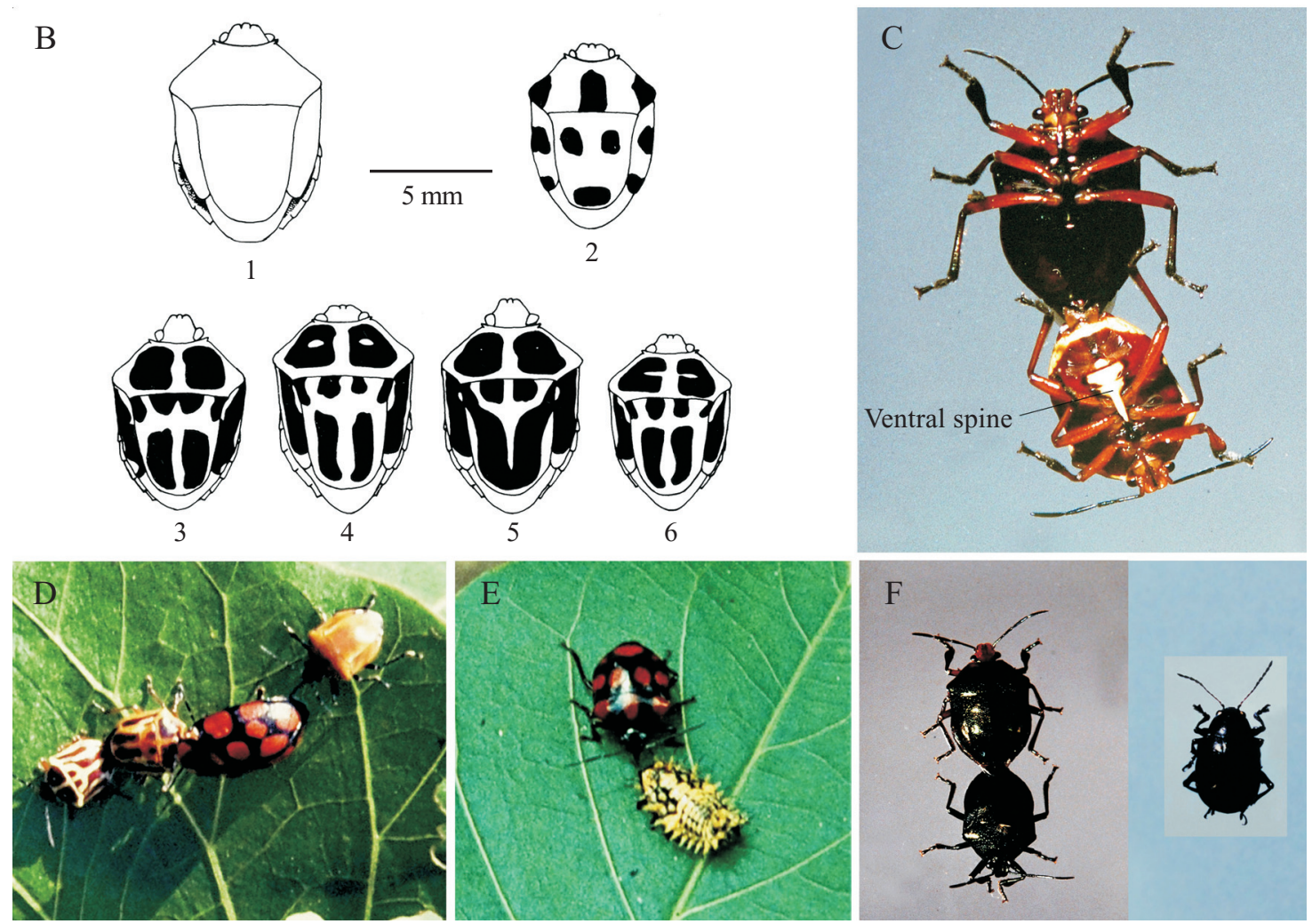

Fig. 2. Adults of Stiretrus decemgutattus: Color patterns variegated (A 1-8, 11-14 and B 2-6) and not variegated (A 9, 10, 15 and B 1); Ventral aspect of adults (C); Three adults preying on a female of Botanochara sedecimpustulata (D); adult color pattern very similar to the B. sedecimpustulata (E); pair very similar to adult (right) of crysomelid Eumolpinae (F); for details of adult color patterns see Table I.

Food preference tests. Botanochara sedecimpustulata predation by $S$. decemgutattus in laboratory, during the four hours (Table II), showed 57 predated larvae, corresponding to $40.7 \%$ of the 67 attacks, $75.44 \%$ of individuals in fourth and fifth instars. First to third instars larvae, eggs, and pupae sustained 14 , six and four attacks, respectively, represent the development stages of least interest to $S$. decemgutattus. In these experiments, in which the preference of S. decemguttatus for one of the stages of development of the prey was investigated, 56 males and 17 females did not attack any prey during $4 \mathrm{~h}$ of observation. However, in this interval of time, many of them fed on a portion of I. asarifolia leaf placed on the respective dishes.
Table II. Eggs, larvae, and pupae of Botanochara sedecimpustulata preyed by Stiretrus decemgutattus in laboratory.

\begin{tabular}{|c|c|c|c|c|c|}
\hline \multirow{3}{*}{ S. decemguttatus } & \multicolumn{4}{|c|}{ Developmental stage } & \multirow{3}{*}{$\begin{array}{c}\text { Total } \\
\text { consumption }\end{array}$} \\
\hline & \multirow{2}{*}{ Eggs } & \multicolumn{2}{|c|}{ Larvae (instars) } & \multirow{2}{*}{ Pupae } & \\
\hline & & $1^{\text {th }}$ to $3^{\text {th }}$ & $4^{\text {th }}$ to $5^{\text {th }}$ & & \\
\hline Male*56 $(\mathrm{N}=70)$ & 1 & 3 & 9 & 1 & 14 \\
\hline Female*17 $(\mathrm{N}=70)$ & 5 & 11 & 34 & 3 & 53 \\
\hline Total consumption & 6 & 14 & 43 & 4 & 67 \\
\hline
\end{tabular}

* Males and females did not attack any prey.

Offered a choice between larvae of B. sedecimpustulata and of $Z$. lineata (Table III), males and females of $S$. 
decemguttatus did not demonstrate a preference for either of these Cassidinae species $\left(\chi^{2}=1.8346 / \mathrm{GL}=1 ; \mathrm{P}>0.05\right)$, nor was the higher predation of $Z$. lineata larvae by the males statistically significant $\left(\chi^{2}=1.0362 ; \mathrm{GL}=1 ; \mathrm{P}>0.05\right)$.

Table III. Fifth instar larvae of Botanochara sedecimpustulata and Zatrephina lineata consumed by Stiretrus decemgutattus adults in laboratory.

\begin{tabular}{lccc}
\hline \multirow{2}{*}{$\begin{array}{c}\text { Adults } \\
\text { S. decemguttatus }\end{array}$} & \multicolumn{4}{c}{ Fifth-instar lavae } \\
\cline { 2 - 4 } & B. sedecimpustulata & Z. lineata & Total consumption \\
\hline Male $(\mathrm{N}=70)$ & 29 & 41 & 70 \\
Female $(\mathrm{N}=70)$ & 37 & 33 & 70 \\
\hline Total consumption & 66 & 74 & 140 \\
\hline
\end{tabular}

Developmental biology. The predator's courting ritual, which was observed in the laboratory, usually takes place in the late afternoon soon after an oviposition. Sexually mature male faces and approaches the female, stimulating her with the ventral spine (Fig. 2C) that individuals of both sexes have, touching the female's cervical region several times prior to copulation. Copulation occurs with individuals facing away each other, the pair then remains in this position for several hours, during which the male is dragged by the female wherever she goes and does not feed, while she does it normally.

The preoviposition period of $S$. decemgutattus lasts about three and a half days and the average number of eggs per female was $52.42 \pm 5.85$, with $41.25 \pm 5.60$ viable eggs, with typically 13 clutches (Fig. 3A), but up to 14, on moist paper covering the dishes. There was no parental care. The egg incubation period of $S$. decemgutattus in the laboratory was six days (Table IV). Although there was uniformity among the individuals monitored in this phase, cases were found of hatching in five days.

$S$. decemgutattus nymphs began preying on larvae only in the second instar, when they were also observed sucking on I. asarifolia leaves. During this instar, four of them did not prey on larvae but fed exclusively on the sap of the leaves, without death or delayed development.

When each breeding box of the $S$. decemguttatus pairs received a pair of $B$. sedecimpustulata due to the scarcity of immature stages in late January, some $B$. sedecimpustulata females oviposited and in these conditions, as in the field, their eggs were attacked, not the females. In general, few adult Cassidinae were predated, and the asopine bug restricted their feeding to I. asarifolia kept in the breeding boxes. After offering these adult preys in early February, no marked change was found in the survival of $S$. decemguttatus; oviposition continued for another five days (Fig. 4). The two longest living individuals lived another 21 and 23 days, up to the end of February and the beginning of March, when almost all $B$. sedecimpustulata adults were already in diapause.

From the first to the fourth instars, the development time increases, varying from $2.36 \pm 0.06$ to $3.31 \pm 0.06$ (Table IV), which were relatively short increases compared to that of the fifth instar, $5.95 \pm 0.08$, which is expected due to the greater morpho-physiological changes taking place in this phase. Proportionally, an increase was found in the consumption of larvae, which went from $1.58 \pm 0.09$ in the second instar to $5.20 \pm 0.21$ in the fifth (Table IV). The accumulated mortality rate during the juvenile stages was $8.33 \%$, with the highest number of deaths in the fifth instar (Table IV).

Table IV. Duration of the developmental stages of Stiretrus decemgutattus and their consumption, respectively, of the Botanochara sedecimpustulata larvae $\left(5^{\text {th }}\right.$ instar $)$, in laboratory.

\begin{tabular}{lccc}
\hline $\begin{array}{c}\text { Developmental } \\
\text { stage }\end{array}$ & $\mathrm{n}$ & $\begin{array}{c}\text { Developmental time } \\
(\mathrm{x} \pm \mathrm{sd})\end{array}$ & $\begin{array}{c}\text { Larvae } \\
\text { consumption }\end{array}$ \\
\hline Egg & 59 & $6.00+0.00(6-6)$ & 0 \\
N1 & 59 & $2.36+0.06(2-3)$ & 0 \\
N2 & 58 & $2.62+0.07(2-4)$ & $1.58+0.09(0-2)^{1}$ \\
N3 & 57 & $2.67+0.35(2-4)$ & $1.95+0.11(0-4)^{1}$ \\
N4 & 55 & $3.31+0.06(2-4)$ & $2.61+0.14(0-4)^{1}$ \\
N5 & 55 & $5.95+0.08(5-8)$ & $5.20+0.21(0-9)^{1}$ \\
Adult & 53 & $22.10+1.67(2-40)$ & - \\
Male & 28 & $20.29+1.53(6-9)$ & $1.70+0.22(0-3)^{2}$ \\
Female & 25 & $23.91+1.75(2-40)$ & $3.70+0.39(1-7)^{2}$ \\
\hline Total & & $43.70+1.09(24-62)$ & -
\end{tabular}

${ }^{1}$ Total prey consumption in the period; ${ }^{2}$ Average number of prey in the first four days after emergence.

The reproductive peak of the population occurred in late January at the beginning of the adult stage (Fig. 4 and Table $\mathrm{V})$ and a higher average contribution of eggs per female between the $10^{\text {th }}$ and $15^{\text {th }}$ days. S. decemgutattus showed a high growth potential in the laboratory at the end of a generation $(T=12.7$; with $r=0.26)$, with a net contribution of $R_{0}=26.3$ eggs per female (Table V).

Table V. Life table of Stiretrus decemgutattus: x, age at beginning of interval (days); $\mathrm{n}$, number of alive females at the beginning of each interval; $1 \mathrm{x}$, proportion of females alive at the beginning of age interval; $\mathrm{dx}$, proportion of female deaths in each interval; qx, proportion of dead females in relation to the number starting each interval; Fx, the sum of eggs; $\mathrm{mx}$, expected daughters; $1 \mathrm{xmx}$, reproductive expectation.

\begin{tabular}{rrrllrrr}
\hline $\mathrm{x}$ & $\mathrm{n}$ & \multicolumn{1}{c}{$\mathrm{lx}$} & \multicolumn{1}{c}{$\mathrm{dx}$} & \multicolumn{1}{c}{$\mathrm{qx}$} & $\mathrm{Fx}$ & $\mathrm{mx}$ & $1 \mathrm{xmx}$ \\
\hline 0 & 24 & 1.0000 & 0 & 0 & 0 & 0 & 0 \\
5 & 24 & 1.0000 & 0.1250 & 0.1250 & 73 & 3.0 & 3.0 \\
10 & 21 & 0.8750 & 0 & 0 & 263 & 12.5 & 11.0 \\
15 & 21 & 0.8750 & 0.0833 & 0.0952 & 186 & 8.9 & 7.8 \\
20 & 19 & 0.7917 & 0.0417 & 0.0526 & 102 & 5.4 & 4.3 \\
25 & 18 & 0.7500 & 0.5417 & 0.7222 & 4 & 0.2 & 0.2 \\
30 & 5 & 0.2083 & 0.1250 & 0.6000 & 2 & 0.4 & 0.1 \\
35 & 2 & 0.0833 & 0.0417 & 0.5000 & 0 & 0 & 0 \\
40 & 1 & 0.0417 & 0.0417 & 1.0000 & 0 & 0 & 0 \\
45 & 0 & 0 & 0 & 0 & 0 & 0 & 0 \\
\hline Total & & & & & 630 & 30.4 & 26.3 \\
\hline
\end{tabular}

Net replacement rate: $\mathrm{R}_{0}=26.3$; Mean generation time: $\mathrm{T}=12.7$; Instantaneous rate of population increase: $\mathrm{r}=0.26$. 


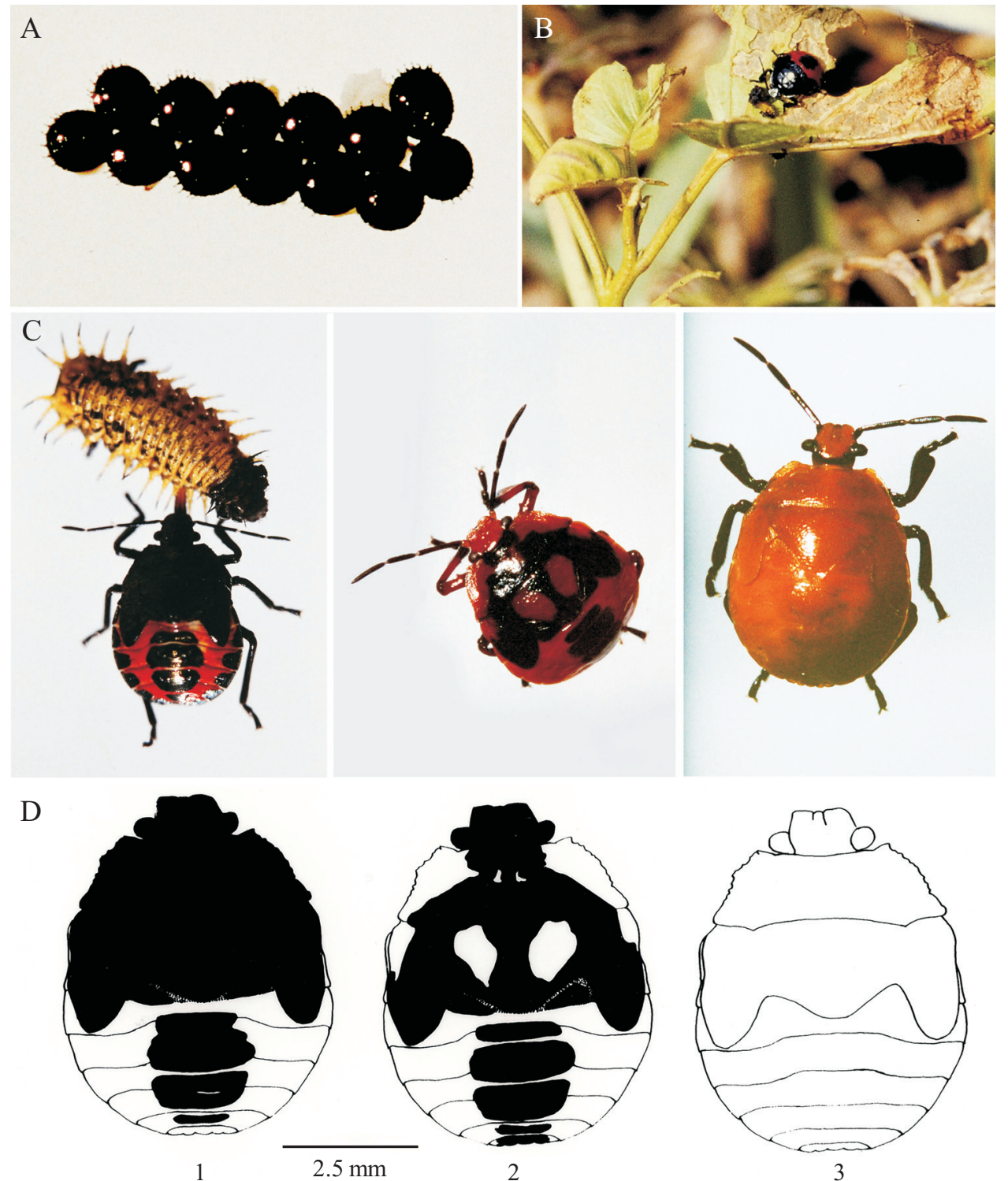

Fig. 3. Immature stages of Stiretrus decemgutattus: egg clutch (A); color patterns among nymphs ( $5^{\text {th }}$ instar) of Stiretrus decemgutattus (B-D).

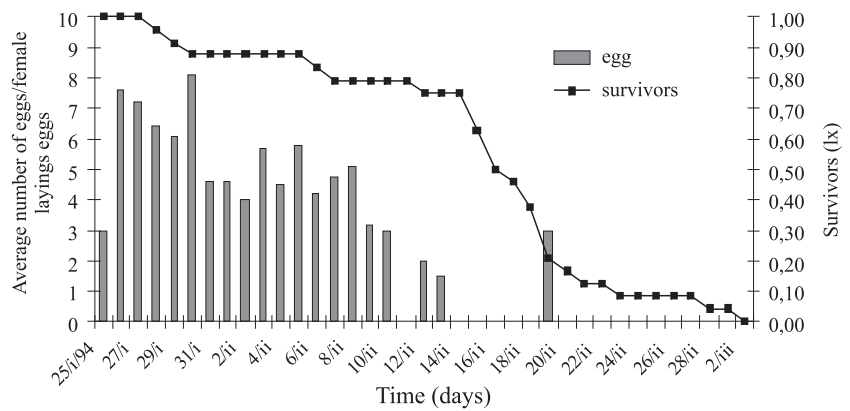

Fig. 4. Fecundity and survivorship curve of Stiretrus decemgutattus.

\section{DISCUSSION}

During the thirty-four months of observations, nymphs and adults of $S$. decemguttatus fed mainly on cassidine lar- vae of late instar in the field and in the laboratory, when compared to early-instar larvae, pupae, and adults. Only one female adult $B$. sedecimpustulata was attacked by $S$. decemgutattus. A similar finding was reported for adults and nymphs of the predator Oplomus dichrous (Herrich-Schaeffer, 1838) (Pentatomidae) on Leptinotarsa decemlineata (Say, 1824) (Chrysomelidae) (Drummond et al. 1987). In addition to S. decemguttatus obtaining a larger quantity of food per attack (see Krebs \& Davies 1996), it probably is also able to penetrate the integument of these individuals more easily than the egg chorion. Another advantage of the preferential predation on late-instar larvae is that they are solitary and their exuvio-fecal annex (Buzzi 1988) is already loose due to the partial or complete loss of the exuviae attached to the anal furculae. In addition, grouped larvae from first to third instars of $B$. sedecimpustulata and $Z$. lineata were observed repelling $S$. decemgutattus by cycloalexic behavior 
(Jolivet et al. 1990; Vasconcellos-Neto \& Jolivet 1988, 1994), as has been reported by Eisner et al. (1967) and Noerdjito et al. (1992). Pereira et al. (2009) observed Harpactor angulosus (Lepeletier and Serville, 1825) (Hemiptera, Reduviidae) preying Hylesia spp. (Lepidoptera) larvae, which were also mainly isolated. The predator could achieve greater success by avoiding massive defense of the larvae, which is very aggressive with strong body movements associated with the release of a regurgitated with greenish color (Specht et al. 2006). Adult beetles, on the other hand, might offer the predator substantial amounts of nutritious material, but besides being well protected, especially on the abdomen covered with elytra, they can fly and escape the threat of an attack.

Neither males nor females of $S$. decemguttatus preferred any of these Cassidinae species, even though under attack, $B$. sedecimpustulata larvae moved their bodies more vigorously than $Z$. lineata larvae, repelling the predator, which sometimes attacked other species. Although, it seems that $S$. decemguttatus can get similar quality and quantity of resources from both species, by not showing any preference in the laboratory, its preference or effects on the dynamics of prey populations in the field was not studied.

Stiretrus decemgutattus nymphs began preying on larvae from the second instar, when they also suck I. asarifolia leaves or fed exclusively on sap of the leaves, without subsequent death or delayed development. Although, a strong preference of adult $S$. decemguttatus for one of the stages of the prey was found in the present study, over half individuals did not attack any beetle larva and many of them, on the other hand, sucked a portion of I. asarifolia leaf on the respective dishes. This habit of consuming plant and prey (omnivory) is common to many arthropods (Coll \& Guerson 2002). The implications of this behavior on the biology and ecology of these animals are poorly studied (Eubanks \& Stryrsky 2005; Kaplan \&Thaler 2011). However, based on functional and numerical responses of omnivorous predators Eubanks (2005) stated that knowing the role of diet on development and reproduction of these species may add relatively little about the dynamics of its interactions. Other predatory Hemiptera also benefit from the host plant of their prey (Castañe et al. 2011; Lykouressis et al. 2008; Naranjo \& Stimac 1985; Salas-Aguilar \& Ehler 1977; Valicente \& O'Neil 1995). The survival of Podisus maculiventris (Say, 1832) (Pentatomidae) increases and its development time and preoviposition period decrease when it feeds on potato leaves (Ruberson et al. 1986). However, this predator does not survive the second instar exclusively on plant diet, in this regard differing from nymphs of $S$. decemguttatus. In the dry season, which in Marajó begins to be felt in March and reaches its height between September and November (OAS 1974), the prey population is so reduced (Paleari 1997) that $I$. asarifolia may assume an important role in the maintenance of the asopine bugs. However, physiological conditions of this host plant need to be studied because its leaves become more coriaceus and with reduced water content.
Stiretrus decemgutattus maintains a complex interaction with both Cassidinae prey and I. asarifolia. This is partially due to specific phenology of $B$. sedecimpustulata prey that restarts its reproductive activities in December, when a significant growth of the population is recorded, and declines sharply between February and March (Paleari 1997). The diapause of $B$. sedecimpustulata represents a negative impact on the predator due to the increase consumption of larvae, greater morpho-physiological changes from the first to the fifth instar, the reproductive peak of the $S$. decemgutattus population at the beginning of the adult stage and its high growth potential in the laboratory at the end of a generation, with a net contribution of $R_{0}=26.3$ eggs per female. This feature should result in a further negative impact on populations of $Z$. lineata, which becomes the main target of the asopine bugs, with the onset of diapause of $B$. sedecimpustulata. Although $S$. decemguttatus did not prefer either prey species in the laboratory, it is more easily found in the environment after diapause, not only due to its high density but also because it exposes itself and its eggs more, both usually conspicuous on the younger leaves that stand out in patches of Ipomoea asarifolia.

A large variety of color patterns of $S$. decemguttatus adults and nymphs (Figs. 2 and 3) was found in Ilha do Marajó. $S$. decemguttatus preying on Paraselenis flava (Linnaeus, 1758) (Chrysomelidae) larvae and pupae in Suriname, showed only two patterns (Van Doesburg 1970) resembling those of Figs. 2A 9 and 10 (nonmetallic), 2A 15 (metallic) and 2A 1 (circular spots design). The pattern of circular designs was unique and found only in males. If this finding is not an artifact of the brevity of author's survey, it may represent the genetic composition of that population, which is different than those found in the present study, since in Salvaterra males are not monomorphic and most common patterns are those of Figs. 2A 9 and 10 (nonmetallic) and Figs. 2A 2 to 8 and 11 to 14, which Van Doesburg (1970) observed only in females.

The presence of a well-developed scutellum allied to the color patterns recorded makes $S$. decemguttatus very similar to the Cassidinae that feed on I. asarifolia (Fig. 2E and 2F; Table I - 9, 14, 17) and suggests the possible existence of mimicry, according to the hypothesis put forward by Van Doesburg (1970) after finding close similarities between $S$. decemguttatus and Chrysomelidae, especially Doryphora aestuans Linnaeus, 1758, which coexisted in Suriname. This explanation is more exciting considering that certain patterns (3, 4, 6, 7, 8 and 9, see Table I and Fig. 2E) involve colors generally found on aposematic insects (Brower \& Brower 1964; Rothschild $1972 \mathrm{a}, \mathrm{b}$ ), and that this asopine bug complements its food with $I$. asarifolia sap, which has toxic effects when ingested by cattle (Barbosa et al. 2005; Tortelli et al. 2008). It is possible that $S$. decemgutattus acquires defense against natural enemies by storing secondary toxic products in its body (Duffey 1980), or by synthesizing new compounds from sap of the plant (Pasteels et al. 1983). On the other hand, the patterns of individuals 10 and 11 (Table I) are similar to those of adult $Z$. lineata in the dry period of the year, when the latter take on a reddish brown color resembling 
that of the vegetation, which provides a certain degree of camouflage. Fifth instar nymphs with different phenotypes (Fig. 3B-C) may originate adults with a similar pattern, while a pair with a given pattern may produce individuals with different color patterns, even from the same egg clutch, a phenomenon also found by Van Doesburg (1970).

Aposematism and/or mimicry signals in S. decemgutattus are interesting evolutionary problems and can play an important role, especially given its common pleiotropic effect (Ford 1975), by acting upon other characteristics determined by the same genes responsible for color patterns.

Natural enemies of adult $S$. decemguttatus were not found during this study. It is possible that they may include a species of reduviid predator of adult $B$. sedecimpustulata, as well as reptiles and birds, which are very common in the region.

In conclusion, our data support that $S$. decemguttatus is an omnivorous and polymorphic species, whose high growth potential should cause a greater impact on the populations of $Z$. lineata than B. sedecimpustulata, and thus favor the population growth of the latter cassidine after diapause, due to an important egg parasitoid being also negatively affected.

The variegated and non-variegated adults of this asopinae bug, whose morphs differ in viability and fecundity - some resembling the markings of chrysomelids associated with Ipomoea asarifolia - integrate a complex system involving much more than simple advantages related to aposematism and/or mimicry of $S$. decemguttatus. For this, mating forms, type of genetic inheritance, viability, fecundity and frequency of the different patterns throughout the year are interrelated aspects which should be studied and analyzed as a whole in order to understand the ecological significance of this polychromism.

\section{ACKNOWLEDGEMENTS}

I would like to thank Dr. Jocélia Grazia for helping in the identification of the Pentatomidae and for reading the manuscript and contributing with valuable comments. To Dr. Luciano A. Moura for helping in the identification of the Eumolpinae. To CNPq for financial support (300807/90-2).

\section{REFERENCES}

Barbosa, J.D., Chaves, C.M.O., Duarte, M.D., Peixoto, P.V. \& Tokarnia, C.H. 2005. Intoxicações experimental e natural por Ipomoea asarifolia (Convolvulaceae) em búfalos e outros ruminantes. Pesquisa Veterinária Brasileira 25: 231-234.

Bondar, G. 1953. Pragas novas nas plantas do Brasil, II. Boletim do Campo 9: $20-24$.

Bourdouxhe, L. \& Jolivet, P. 1981. Nouvelles observations sur le complexe mimetique de Mesoplatis cincta Olivier (Coleptere Chrysomelidae) au Senegal. Société Linnéenne de Lyon 2: 46-48.

Brower, L.P. \& Brower, J.V.Z. 1964. Birds, butterflies and plant poisons: a study in ecological chemistry. Zoologica 46: 137-159.

Buzzi, Z.J. 1988. Biology of Neotropical Cassidinae, p. 559-580. In: Jolivet, P.H., Petitpierre, E. \& Hsiao, T.H. (eds.). Biology of Chrysomelidae. Dordretcht, Kluwer, xxiv+615 p.

Buzzi, Z.J. 1994. Host plants of Neotropical Cassidinae, p. 205-212. In: Jolivet, P.H., Cox, M.L. \& Petitpierre, E. (eds.). Novel Aspects of the Biology of Chrysomelidae. Dordrecht, Kluwer, xxiii+582 p.
Castañé, C., Arnó, J., Gabarra, R. \& Alomar, O. 2011. Plant damage to vegetable crops by zoophytophagous mirid predators. Biological Control 59: 22-29.

Coll, M. \& Gershon, M. 2002. Omnivory in terrestrial arthropods: mixing plant and prey diets. Annual Review of Entomology 47: 267-297.

Drummond, F.A., Casagrande, R.A. \& Groden, E. 1987. Biology of Oplomus dichrous (Heteroptera:Pentatomidae) and its potential to control Colorado potato beetle (Coleoptera:Chrysomelidae). Environmental Entomology 16: 633-638.

Duffey, S.S. 1980. Sequestration of plant natural products by insects. Annual Review of Entomology 25: 447-477.

Eisner, T., Tassel, E. \& Carrel, J.E. 1967. Defensive use of a fecal shield by a beetle larva. Science 158: 1471-1473.

Eubanks, M.D. 2005. Predaceous herbivores and herbivorous predators The biology of omnivores and ecology of omnivore-prey interactions, p. 3-16. In: Barbosa, P. \& Castellanos, I. (eds.) Ecology of predatorprey interactions. Oxford, Oxford University Press, xvii+394 p.

Eubanks, M.D. \& Stryrsky, J.D. 2005. Effects of plant feeding on the performance of omnivorous "predators", p. 148-177. In: Wäckers, F.L., van Rijn, P.C.J. \& Bruin, J. (eds.) Plant-provided food for carnivorous insects: a protective mutualism and its application. Cambridge, Cambridge University Press, xii +356 p.

Ford, E.B. 1975. Ecological genetics. London, Chapman and Hall, 442 p.

Freeland, W.J. 1983. Parasite and the coexistence of animal host species. American Naturalist 121: 223-236.

Jolivet, P., Vasconcellos-Neto, J. \& Weinstein, P. 1990. A new concept in the larval defense of insects. Insecta Mundi 4: 133-142.

Kaplan, I. \& Thaler, J.S. 2011. Do plant defenses enhance or diminish prey suppression by omnivorous Heteroptera? Biological Control 59: 53-60.

Krebs, J.R. \& Davies, N.R. 1996. Introdução à Ecologia Comportamental. São Paulo, Atheneu, xi+420 p.

Lawton, J.H. 1986. The effect of parasitoids on phytophagous insect communities, p. 265-287. In: Waage, J. \& Greathed, D. (eds.). Insect parasitoids. London, Academic Press, 389 p.

Naranjo, S.E. \& Stimac, J.L. 1985. Development, survival, and reproduction of Geocoris punctipes (Hemiptera: Lygaeidae): effects of plant feeding on soybean and associated weeds. Environmental Entomology 14: 523-530.

Lykouressis, D., Giatropoulos, A., Perdikis, D. \& C. Favas 2008. Assessing the suitability of noncultivated plants and associated insect prey as food sources for the omnivorous predator Macrolophus pygmaeus (Hemiptera: Miridae). Biological Control 44: 142-148.

Moura, L.A. \& Grazia, J. 2011. Record of Podisus nigrispinus (Dallas) (Hemiptera: Pentatomidae) preying on Metrogaleruca obscura Degeer (Coleoptera: Chrysomelidae). Neotropical Entomology 40: 619-621.

Naranjo, S.E. \& Stimac, J.L. 1985. Development, survival, and reproduction of Geocoris punctipes (Hemiptera: Lygaeidae): effects of plant feeding on soybean and associated weeds. Environmental Entomology 14: 523-530.

Noerdjito, W.O., Ito, F. \& Nakamura, K. 1992. Effects of ants on larvae of the tortoise beetle Aspidomorpha santaecrucis (Chrysomelidae) on a shrubby morning glory, p. 45-48. In: Nakamura, K. \& Katakura, H. (eds.). Evolutionary biology and population dinamics of herbivorous ladybeetles in Indonesia. Sapporo, published by the editors.

OAS, 1974. Marajó: um estudo para o seu desenvolvimento. Washington, Secretaria Geral da Organização dos Estados Americanos.

Paleari, L.M. 1994. Variação sasonal de frequência e abordagem genética dos padrões de cor de Agonosoma flavolineatum Laporte, 1832 (Hemiptera, Scutelleridae). Revista Brasileira de Entomologia 38: 47-56.

Paleari, L.M. 1997. Partilha de recurso entre Botanochara sedecimpustulata e Zatrephina lineata (Chrysomelidae, Cassidinae), em Ipomoeae asarifolia (Convolvulaceae), na Ilha de Marajó, Pará, Brasil. Ph. D. dissertation. Campinas, Universidade Estadual de Campinas, 109 p.

Pasteels, J.M., Gregoire, J.C. \& Rowell-Rahier, M. 1983. The chemical ecology of defense in arthropods. Annual Review of Entomology 28: 263-289.

Pereira, A.I.A., Zanuncio, J.C., Gil-Santana, H.R., Ramalho, F.S., Leite, G.L.D. \& Serrão, J.E. 2009. Harpactor angulosus (Reduviidae: 
Harpactorinae): a predator of neotropical Saturniids, Hylesia spp. Entomological News 120: 206-121.

Poncio, S., Dequech, S.T.B., Sturza, V.S., Lissner, R.A.D., Perlin, L.F., Rosalino, P.K. \& Ribeiro, L.P.. 2010. First report of Stiretrus decastigmus in Brazil preying Microtheca ochroloma. Ciência Rural 40: 1203-1205.

Rothschild, M. 1972a. Colour and poisons in insect protection. New Scientist 11: 318-320.

Rothschild, M. 1972b. Some observations on the relationship between plants, toxic insects and birds, p. 112. In: Harborne, J.B. (ed.). Phytochemical ecology. London, Academic Press, 156 p.

Ruberson, J.R., Tauber, M.J. \& Tauber, C.A. 1986. Plant feeding by Podisus maculiventris (Heteroptera: Pentatomidae): effect on survival, development, and preoviposition period. Environmental Entomology 15: 894-897.

Salas-Aguilar, J. \& Ehler, L.E. 1977. Feeding habits of Orius tristicolor. Journal of the New York Entomological Society 70: 60-62.

Specht, A., Formentini, A.C. \& Corseuil, E. 2006. Biologia de Hylesia nigricans (Berg) (Lepidoptera, Saturniidae, Hemileucinae). Revista Brasileira de Zoologia 23: 248-255.

Thomas, D.B. 1992. Taxonomics synopsis of the Asopinae Pentatomidae (Heteroptera) of the Western Hemisfere. Thomas Say Foundation
Monographs. Lanham, Entomological Society of America, $147 \mathrm{p}$

Tortelli, F. P., Barbosa, J.D., Oliveira, C.M.C., Duarte, M.D., Cerqueira, V.D., Oliveira, C. A., Correa, F.R. \& Correa, G.R.. 2008. Intoxicação por Ipomoea asarifolia em ovinos e bovinos na Ilha de Marajó. Pesquisa Veterinária Brasileira 28: 622-626.

Valicente, L.H. \& O’Neil, R.J. 1995. Effects of host plants and feeding regimes on selected life history caracteristics of Podisus maculiventris (Say) (Heteroptera: Pentatomidae). Biological Control 5: 449-461.

Van Doesburg, P.H.,Jr. 1970. Polymorphism in some neotropical Asopinae (Heteroptera: Pentatomidae). Actas del Cuarto Congresso Latinoamericano de Zoologia 1: 235-238.

Vasconcellos-Neto, J. 1988. Genetics of Chelymorpha cribraria, Cassidinae: color patterns and their ecological meanings p. 217-232. In: Jolivet, P., Petitpierre, E. \& Hisiao, T.H (eds.). Biology of Chrysomelidae. Dordrecht, Kluwer, 608 p.

Vasconcellos-Neto, J. \& Jolivet, P. 1994. Cycloalexy among chrysomelid larvae, p. 303-309. In: Jolivet, P., Cox, M.L. \& Petitpierre, E. (eds.). Novel aspects of the biology of Chrysomelidae. Dordrecht, Kluwer, xvi $+582 \mathrm{p}$.

Vasconcellos-Neto, J. \& Jolivet, P. 1988. Une nouvelle stratégie de defense: la stratégie de défense annulaire (cicloalexie) chez quelques larves de Chrysomelidae bresiliens. (Col.). Bulletin de la Société Entomologique de France 92: 291-299. 